Research, part of a Special Feature on Law and Social-Ecological Resilience

\title{
Resilience and Water Governance: Adaptive Governance in the Columbia River Basin
}

\author{
Barbara A. Cosens ${ }^{1,2}$ and Mark Kevin Williams ${ }^{3}$
}

\begin{abstract}
The 1964 Columbia River Treaty between the United States and Canada is currently under review. Under the treaty, the river is jointly operated by the two countries for hydropower and is the largest producer of hydropower in the western hemisphere. In considering the next phase of international river governance, the degree of uncertainty surrounding the drivers of change complicates efforts to predict and manage under traditional approaches that rely on historical ecosystem responses. At the same time, changes in social values have focused attention on ecosystem health, the decline of which has led to the listing of seven salmon and four steelhead populations under the U.S. Endangered Species Act. Although adaptive management is considered one approach to resource management in the face of uncertainty, an early attempt at its implementation in the U.S. portion of the basin failed. We explore these issues in the context of resilience, taking the position that while adaptive management may foster ecological resilience, it is only one factor in the institutional changes needed to foster social-ecological resilience captured in the concept of adaptive governance.
\end{abstract}

Key Words: adaptive governance; Columbia River basin; law, resilience

\section{INTRODUCTION}

Political boundaries are drawn without consideration of river basin boundaries, as evidenced by the existence of 276 surface water resources that cross international boundaries (Oregon State University, Program in Water Conflict Management and Transformation, Transboundary Freshwater Dispute Database, URL: http://www.transboundarywaters.orst.edu/database/) and many more that cross sub-national jurisdictional boundaries. Over the next decade, several contributing factors could trigger rapid change in these international watersheds, placing greater demands on competing water interests and increasing the need for cooperation across jurisdictional boundaries. These contributing factors include: climate change, continued population growth, a threatened and deteriorating ecosystem, demand for non-fossil fuel energy, and aging infrastructure. Uncertainty in these factors creates challenges for traditional approaches to the governance of transboundary water resources.

This research is an outgrowth of the work of the Universities Consortium on Columbia River Governance focused on transboundary water governance. It uses the natural laboratory of the Columbia basin, shared by the United States and Canada, as a focal point for discussion. Joint operation of the river for hydropower production and flood control is governed by a 1964 treaty (hereafter, the Treaty). Certain flood control provisions of the Treaty expire in 2024, and either country must provide $10 \mathrm{yr}$ notice should it seek to terminate the Treaty. Thus, efforts are underway in the basin that attempt to predict changes and to understand whether the predicted changes warrant Treaty modification. In addition, many view Treaty review as an opportunity to connect domestic and local efforts on ecosystem restoration to international operations under the Treaty and to bring greater transparency and avenues for public input to implementation decisions. The degree of uncertainty surrounding the drivers of change complicates these efforts and has led to a search for an approach to governance that accounts for uncertainty, rather than seeking further technological means to constrain it.

In complex systems that have high degrees of uncertainty, like the Columbia River, emerging theories point to the importance of assessing and actively managing system resilience, i.e., the extent to which a system can absorb recurrent natural and human perturbations and continue to maintain essential function without slowly degrading or even unexpectedly flipping into a less desirable state (Folke et al. 2005). System management for resilience, as opposed to management to optimize a single resource function (e.g., hydropower production), introduces its own uncertainties as a result of the complex interactions and feedbacks within the system (Holling and Gunderson 2002). Thus, proponents of management for resilience suggest the use of adaptive management to allow adjustments in the face of change (Holling 1978, Lee 1999, Folke et al. 2005, Huitema et al. 2009) while noting that a change to management focused on ecosystem resilience will "require new forms of human behavior with a shift in perspective from the aspiration to control change in systems, assumed to be stable, to sustain and generate desirable pathways for societal development in the face of increased frequency of abrupt change" (Folke et al. 2005:443).

\footnotetext{
${ }^{1}$ University of Idaho College of Law, ${ }^{2}$ Waters of the West Program, ${ }^{3}$ Carr Center for Human Rights Policy, Human Right to Water and Sanitation Program, Harvard Kennedy School of Government
} 
Human behavior, however, does not shift in perspective simply because science indicates it is the right thing to do. Acceptance of decisions, whether supported by science or not, requires legitimacy in the actions of the institutions of governance that are making and implementing those decisions. Legitimacy is challenged by the degree of flexibility required by adaptive management. For resilience scientists, there is currently a gap between theory and application. On the one side, they recognize that adaptive management is an appropriate management tool in the face of uncertainty. However, they also recognize the difficulty in achieving practical implementation of adaptive management. This gap may be bridged by recognizing the difference between scientific accuracy and social legitimacy and the full integration of the social component. It is not enough that monitoring and incremental adjustment will provide the best ecological results in the face of uncertainty. The decisions whether to use adaptive management, what to monitor, and how to make incremental adjustment must be made in a manner that fosters legitimacy.

Thus, achieving the implementation of adaptive management requires attention to the process of governance used to carry it out. In this context, "governance is the process of resolving trade-offs and of providing a vision and direction for sustainability, management is the operationalization of this vision..." (Boyle et al. 2001:122). By its definition, governance will involve trade-offs and thus may not lead to the perfect scientific result for the ecological system. However, the flaw in implementing adaptive management without integrating the social component is that it makes the same mistake as traditional management by optimizing for a subset of the system, i.e., the ecosystem. Coupled with adaptive management, an appropriate form of governance addresses the entire social-ecological system.

Our work builds upon the work of scientists to define criteria for adaptive governance by turning to legal scholarship on legitimacy to explain why certain aspects of governance are necessary if flexible, experimental approaches to management are to gain acceptance. It uses a framework on legitimacy developed by Cosens $(2010,2012)$ and summarized next to argue for a renewed but restructured attempt at adaptive management within a framework of adaptive governance applied to the Columbia River basin social-ecological system.

\section{ADAPTIVE GOVERNANCE AND LEGITIMACY}

In resilience literature, scholars use the term governance to describe the laws, policies, regulations, institutions, and institutional structures involved in governing (Folke et al. 2005, Huitema et al. 2009). The term adaptive management has been used to describe a process of learning through monitoring ecosystem response to a particular action, followed by incremental change in the action based on what is learned (Holling 1978, Lee 1999, Folke et al. 2005, Huitema et al.
2009). Adaptive management is only one of many management approaches that a system of governance might use to implement its policies. It is an approach designed to address the inherent uncertainties in a system's response to management changes. It has also been viewed as an alternative to traditional forms of resource management that focus on optimizing for specific aspects of an ecosystem that match current economic needs or political goals. The failure of management through optimization to retain the full range of ecosystem services is a key message of scholars working on resilience theory (Walker and Salt 2006, Zellmer and Gunderson 2009).

The term adaptive governance has been employed to describe a governance process that responds to feedback received by a managing agency from monitoring the response of the ecosystem (i.e., adaptive management). It does this through collaboration and cooperation across different levels of government, non-governmental, and individual actions and among agencies within the same level of government with overlapping authority (Folke et al. 2005). Boyle et al. (2001:122) help clarify the difference between governance and adaptive management by stating that "governance is the process of resolving trade-offs and of providing a vision and direction for sustainability, management is the operationalization of this vision..." We use the term adaptive governance to indicate the type of governance necessary to allow sufficient flexibility for adaptive management.

Adaptive governance moves from a focus on efficiency and lack of overlap among jurisdictional authorities to a focus on diversity, redundancy, and multiple levels of management that include local knowledge and local action. Huitema et al. (2009) set forth four criteria for adaptive governance: polycentricity (also referred to as legal pluralism in legal scholarship; Roth et al. 2005), public participation, an experimental approach to resource management, and management at the bioregional scale. One problem in evaluating these components of adaptive governance is the inability to measure the effects of implementing each criterion.

Huitema et al. (2009) find no concrete evidence that polycentric governance is more flexible and less vulnerable (key goals for facilitation of resilience) than traditional, hierarchical forms of governance. Instead, they find that numerous case studies suggest the effectiveness of the polycentric approach for large-scale, common-pool resources (Langston 2003, Huitema et al. 2009). They also note, "there is little empirical evidence for the effectiveness of the riverbasin approach, either in its monocentric form (unitary riverbasin authorities) or its polycentric form (collaboration at the basin scale), in the literature discussed here. Dinar et al. suggest that basin-level governance institutions are a necessary but insufficient condition for successful resource management, meaning that the absence of such institutions 
will lead to the failure of management but their presence does not necessarily lead to success," Huitema et al. (2009:10; citations omitted).

Legal scholars may not find this lack of ability to monitor and provide quantitative proof of effectiveness as disturbing as scientists might. The very nature of complex social-ecological systems, the fact that no two large-scale systems are exactly alike, and the fact that no system is ever identical at two different points in time, renders it impossible to make a controlled comparison of polycentric and hierarchical governance. More importantly, legal scholarship adds a different approach to analyzing the necessary components of adaptive governance. Rather than asking how to measure whether the criteria that define adaptive governance lead to better results, the disciplinary perspective we accept here is the need for a more flexible and experimental approach to water resource management in the face of uncertainty and applies the legal and political science literature to understand the components necessary for public acceptance (legitimacy) of that approach. The following paragraphs summarize the requirements necessary to assure legitimacy in governmental decision making that employs an experimental approach to resource management. This is followed by discussion of their relation to the criteria for adaptive governance set forth by Huitema et al. (2009) of polycentricity, public participation, an experimental approach to resource management, and bioregional scale.

Legitimacy is a qualitative term used here to describe the persuasiveness of the basis for a governmental action (Bodansky 1999). It is a fundamental premise of political theory that people seek legitimacy in the actions of those who govern them. The concept has both normative and popular aspects. Thus, to be legitimate, a governmental assertion of authority must be justified (normative) and perceived to be justified (popular; Bodansky 1999).

In the historic range of governmental systems, democracy emerges as a system with a high level of legitimacy because people consent to their leadership through the process of electing those who govern. The increasing implementation of the law by administrative officials, as opposed to elected officials, dilutes the direct connection between the elected official and the voters affected by regulation. Clearly this challenges the legitimacy of decision making even in a democracy. To address this issue in the growing administrative state, administrative law has developed to fill the gap by governing the processes followed by the agencies that are delegated authority to implement the law. Introducing flexibility to water resource management to allow adaptive management can challenge the administrative processes currently used to assure legitimacy and lead to opposition to adopting new approaches. Analysis of the underlying basis for process elements currently employed in administrative law to assure legitimacy is a starting point for developing additional tools to assure legitimacy in a more flexible approach to management.

Of the five sources of legitimacy in the administrative process outlined by Esty (2006), three are of primary consideration for the implementation of adaptive management: (1) results based: legitimacy derived from the use of objective expertise as the basis for decisions and the ability to determine whether the results are good; (2) order based: legitimacy derived from the adherence by the administrative agency to rules that are clear, stable, and publicly available; and (3) deliberative: legitimacy derived from reliance on a public dialog in the process of decision making. We describe and apply these three sources of legitimacy to the concept of adaptive governance in the following paragraphs. A more thorough discussion of legitimacy and its relation to management for resilience is the topic of other articles by Cosens (2010, 2012); it will be summarized here.

\section{Results-based legitimacy}

Administrative agencies develop results-based legitimacy through reliance on scientific expertise. This began in the United States with federal management of the forests based on forestry science (16 U.S.C. $\$ \S 473-478,479-482$, and 551, June 4, 1897, as amended 1905, 1911, 1925, 1962, 1964, 1968, and 1976). The premise behind science-based decision making is that the process will be objective and the results will improve. The use of scientific expertise as a source of legitimacy is increasingly questioned as agency science shows vulnerability to politicization (Wagner 1995, Doremus and Tarlock 2005, O'Reilly 2007, Cosens 2008, Ruhl and Salzman 2010); however, implementation of adaptive management may serve to cure that vulnerability (Camacho 2009).

Adaptive management, Huitema et al.'s (2009) “experimental approach to management," requires that the results of an agency action be monitored and that the action be adjusted based on the monitoring. Under the current approach to science-based management, substantial resources may be allocated to studying a problem in the process of developing a solution; however, data are rarely gathered to verify the results of a particular action (Shabman et al. 2007, Camacho 2009). Furthermore, even if data were collected following agency action, agencies rarely have the authority to modify the action without going back through the rulemaking process, or in some cases, without new legislation. Although reluctance to provide authority for flexible implementation may lie in part in failure to fund monitoring (Shabman et al. 2007, Camacho 2009), it also reflects a failure to tie adjustment based on monitoring to agency accountability. Actual measurement of results and adjustment in the face of those measurements will enhance results-based legitimacy. It will also reduce the use of science to achieve the goals of a particular interest group. 


\section{Order-based legitimacy}

Order-based legitimacy addresses the need for stability and finality in regulations that affect economic pursuits. Sources of order-based legitimacy in administrative process include rulemaking and judicial review of administrative actions. In the United States, agencies promulgate rules to govern implementation of laws passed by Congress. Rulemaking facilitates the application of law to the regulated community in an equal and uniform manner. Proposed rules are subject to notice and comment, thus increasing the possibility that unintended consequences will be found and addressed before final rules are in place (U.S. Administrative Procedure Act 5 USC §553). The knowledge that the same rules will be applied to all creates a level playing field and provides stability for economic pursuits. Finality is achieved through the judicial review process that allows affected parties to challenge both rules and administrative actions under the rules (U.S. Administrative Procedure Act 5 USC $\S 704)$. Once review of a particular issue makes its way through the courts, res judicata, the concept that a final decision by a court on an issue is conclusive as between the same parties, and stare decises, the judicial policy of following earlier decisions by the same court, prevent or discourage re-litigation to achieve a different outcome, thus providing finality.

The desire for stability and finality is in direct conflict with the flexibility needed for adaptive management. The communication gap between those advocating adaptive management and those seeking finality is found in many legal battles concerning natural resources and the environment and arises from a basic conflict between the goals of science and law. The scientific process is a neverending search for the truth. Litigation is a process intended to reach final resolution (Cosens 2008). Scientific inquiry has no concept of res judicata or stare decises. Instead, scientific methodology is a process of disproving what was formerly thought to be true, with continued re-investigation of questions thought solved and re-interpretation of theories in light of new discoveries (Kosso 2007). Civil litigation serves economic purposes. The goal is final resolution of a dispute to facilitate a return to economic pursuits. Although truth is sought within the limits of the information available at the time, final, peaceful dispute resolution is given higher value than truth. Similarly, the current process of rulemaking is designed to consider the issue once and then proceed under a final rule rather than to reexamine and adjust to the results of the rule's implementation. In disputes concerning the environment, civil litigation serves economic interests by providing stability; science serves environmental interests by continuing the search for the true cause of environmental harm. In this framework, adaptive management, with its continuing adjustment based on science, serves environmental interests but may introduce instability for economic interests.
Bridging this gap first requires an understanding that the environmental community has not been silent in the face of a system of civil litigation that was not designed to achieve their goals. Once the environmental community has exhausted its options within the judicial system, the issues will be revisited in the relevant legislature or Congress. Once all options have been exhausted within the political system, the issues might even be addressed through civil disobedience. An apt example is the endless litigation on the Columbia River over anadromous fish (discussed below) that has led to gridlock in recovery efforts. It is possible that the gridlock in the current system may encourage parties to seek an alternative.

Addressing concerns for stability and finality requires attention to the timeframe for incremental adjustment of management measures. Bringing legitimacy to the incremental approach of adaptive management requires equal treatment of both the economic need for finality and the progress toward the true system understanding needed to address environmental concerns. Examples suggest that currently, management relying on monitoring for adjustment uses a biological timeframe when the management action is developed by a science-based agency (e.g., see U.S. Geological Survey Patuxent Wildlife Research Center, basing monitoring on biological goals), and uses social timeframes when negotiated (e.g., see Snake River Water Rights Settlement 2004 Mediator's Term Sheet of April 20, 2004, placing a 30-yr timeframe on a biological opinion to provide stability for water users in the region). To foster ecological resilience while maintaining legitimacy, both ecological and social timeframes must be built into rulemaking for any adaptive management process.

It is also important to note that a current problem with orderbased legitimacy may actually be addressed by adaptive governance. Fragmentation of water management due to jurisdictional boundaries that may reflect political boundaries among governments or subject matter boundaries among agencies not only frustrates efforts to address an ecosystem as a whole, it also frustrates the regulated community faced with piecemeal and conflicting approaches. The need to address this issue provides support for seeking the ability to coordinate at a bioregional scale in adaptive governance. Research on the use of formal and informal networks to coordinate across multiple entities may provide valuable insights into the management of polycentricity (e.g., Bodin and Crona 2009, Zaring 2009, Ruhl and Salzman 2010).

\section{Deliberative legitimacy}

Deliberative legitimacy is reflected in the growing expectation for public involvement in all aspects of governance and in particular with environmental governance (Hirt and Sowards 2012). It is addressed in agency decision making in the United States in both administrative and substantive environmental 
law. Administrative law requires notice and comment in rulemaking (5 USC §553), open meetings (5 USC §552b) in which public officials are engaged in decision making, and open public records (5 USC §552). In substantive law, the passage of the National Environmental Policy Act (NEPA) in 1969 can be considered the major turning point in public involvement in agency decision making (Hirt and Sowards 2012). NEPA conforms with administrative law requirements that meetings and records be open to the public. However, it goes beyond the administrative law requirements by imposing the affirmative duty on agencies to develop and analyze information on the environmental impact of major federal actions and provide the information to the public for comment (U.S. National Environmental Policy Act 42 USC §4332). Although NEPA does not impose any substantive requirement to choose the most environmentally sustainable alternative (Vermont Nuclear Power Corp. vs. NRDC, 1978), it arms the public with the information necessary to participate in shaping the decision through the political process.

The continued criticism of agency decision making in the United States suggests that public meetings and even the provision of information on environmental impact are insufficient to provide deliberative legitimacy. Adaptive governance requires more than public comment, it requires meaningful public comment; this is a two way flow of information in which governmental agencies work not only to provide information from their own expertise, but to also incorporate local knowledge and work toward a greater role for public input in decision making (McKinney and Harmon 2004). Without strong local capacity building and a meaningful role for local decision making, these requirements of public comment may amount to more form than substance.

Discussions of polycentric governance and legal pluralism view local capacity building for purposes of self-governance as key to effective governance (Hanna 2008, Raadgever et al. 2008, Huitema et al. 2009). Achieving this would require both the infusion of education and resources at the local level and local authority within the decision making network. Polycentric government differs from the move for local control in past Western U.S. efforts such as the Sagebrush Rebellion and the county supremacy movement, which advocate total local control over local natural resource issues concerning federal land. Instead, polycentric governance would require granting a larger voice and decision-making power locally while retaining a network with state and federal government. Small-scale spatial and temporal impacts may be reflected best in local knowledge, improving the knowledge base for a decision. Local experimentation with adaptive management within a stable state or federal framework may meet both the requirements of order-based legitimacy while allowing more robust avenues for deliberation. This redundancy in government, viewed as inefficient in the past, enhances adaptive capacity.
Application of this analysis to the Columbia River basin requires an understanding of human development of the basin, the opportunity presented by review of the Columbia River Treaty (Treaty between Canada and the United States of America Relating to Cooperative Development of the Water Resources of The Columbia River Basin [Columbia River Treaty], United States-Canada, January 17, 1961, URL: http:// www.ccrh.org/comm/river/docs/cotreaty.htm), and analysis of the previous attempt to implement adaptive management in the U.S. portion of the river.

\section{THE COLUMBIA RIVER}

The Columbia River basin covers 259,500 square miles $\left(672,102 \mathrm{~km}^{2}\right)$ in Canada and the United States, with an average annual runoff of 200 million acre-feet (approximately 247 million $\mathrm{m}^{3}$; Barton and Ketchum 2012). The basin includes portions of seven U.S. states, i.e., Washington, Oregon, Idaho, Montana, Nevada, Utah, and Wyoming, and the province of British Columbia in Canada. Despite the fact that only $15 \%$ of the basin lies within Canada, 38\% of the average annual flow and 50\% of the peak flow originates in Canada (Shurts 2012). Importantly, because runoff from snowpack occurs later in the higher latitudes of Canada, $50 \%$ of the critical late summer flow may originate there (Hamlet 2003). This seasonal variability in unregulated peak flow is $1: 34$, a large range compared to that of other major North American rivers, for example, a mere 1:2 on the St. Lawrence River and 1:25 on the Mississippi River (Hamlet 2003). The variability caused 20th century boosters to seek to harness the river's potential for irrigation and energy through storage (Hirt and Sowards 2012). Current storage capacity on the river is $40 \%$ of the average annual flow, which is substantially less than that on the Mississippi River (200\%) and the Colorado River (400$500 \%$ ). The basin relies on natural storage from snowpack to meet current uses of the river. Adaptation will be required of the basin because of increasingly reduced snowpack caused by climate change (Hamlet 2003).

In 1805, when the Lewis and Clark expedition made its way down the Columbia River to Astoria, there were no dams. Salmon fisheries sustained the native population. Falls slowed upriver migration of salmon and provided excellent fishing locations. Each year, thousands of Native Americans from numerous tribes gathered at locations such as Celilo Falls (now inundated by water behind the Dalles Dam) to fish and trade (Hirt 2008, Landeen and Pinkham 2008). This human adaptation to the ecological system was soon to change. Competition from commercial fishing and an influx of canneries began in 1866. The U.S. Army Corps of Engineers (USACE) began transforming the Columbia River for navigation with locks at the Cascades as early as 1896 , with numerous dams to follow (White 1995). Most dams in the U. S. portion of the river mainstem generated hydropower and aided navigation but did not store substantial water (Shurts 2012). Exceptions to this run-of-the-river approach were the 
Grand Coulee Dam, a federal facility, which was completed on the mainstem in 1942 for irrigation and permanently blocked salmon runs from reaching Canada, and the Hungry Horse Dam, completed on the tributary the South Fork of the Flathead in 1953 (Shurts 2012). In 1948, even though the total river flow was near average, runoff occurred rapidly and peaked with a flood in May that destroyed the town of Vanport, Oregon, with estimated flow of $>1$ million cubic feet per second $\left(28,317 \mathrm{~m}^{3} / \mathrm{s}\right.$; average peak flows are less than half that rate; Barton and Ketchum 2012). At the time of the 1948 flood, total storage capacity on the Columbia River was approximately $6 \%$ of the average annual flow (White 2012). Compare this to the Colorado River's storage capacity of more than four times its average annual flow or the Missouri River's storage capacity more than two times its average annual flow (Barton and Ketchum 2012). The approach at the time to Columbia basin flood control issues, which were implemented by the USACE, was to address flood control through storage. However, the USACE was confronted by the fact that the best remaining water storage sites were not located in the United States, but in Canada.

Even before the 1948 flood, the International Joint Commission formed by the 1909 Boundary Waters Treaty between the United States and Canada was directed to study the possibility of storage within Canada to provide flood control or power benefits to both countries (Mouat 2012, Shurts 2012). The Columbia River Treaty, which would form the framework to accomplish this task, was not adopted until 1964. Possibly the biggest obstacle to its completion was the fact that the three new dams contemplated would all be in British Columbia while the majority of flood control and hydropower benefits would be in the United States (Mouat 2012, Shurts 2012). Between 1961 and 1964, negotiations between the federal government of Canada and the province of British Columbia resulted in turning the operation and benefits under the Treaty over to British Columbia; the operations benefits would be divided between the United States and British Columbia (Hirt and Sowards 2012, Mouat 2012, Shurts 2012). The resulting solution has been held throughout the world as the pinnacle of international cooperation on non-navigational uses of freshwater sources (Barton and Ketchum 2012).

The Treaty provided for appointment of operating entities by the United States and British Columbia. The United States selected the Administrator of the Bonneville Power Administration and Division Engineer of the Northwestern Division U.S. Army Corps of Engineers (Executive Order 11,177, 29 Federal Register 13097, September 16, 1964). British Columbia selected BC Hydro (Barton and Ketchum 2012). The entities operate under strict Treaty provisions and do not have decision-making power to modify or adapt the Treaty or to act on public comment.
One further complication needed to be addressed before the Treaty could be completed. In 1964, the Pacific Northwest did not need all of the power the new projects would generate. This problem was solved when Congress authorized construction of the Pacific Northwest-Pacific Southwest Intertie, allowing the sale of power to utilities in the southwestern United States, with a preference for sale to northwest utilities (Pacific Northwest Consumer Power Preference Act, 16 U.S.C. $\S 837.2006)$. This resulted in an interconnected North American power grid.

Certain flood control provisions, paid for upfront by the United States to cover $60 \mathrm{yr}$, expire in 2024 (Treaty Article IV). The Treaty contains no automatic termination date or renegotiation clause; 2024 is the earliest date either party may unilaterally terminate the Treaty (Treaty Article XIX). At least ten years notice of termination must be provided; hence, the entities in the basin are focused on a thorough review of the Treaty before 2014. This has led to consideration of whether the time is ripe for Treaty modification (Shurts 2012), and many others see this as an opportunity to raise concerns with ecosystem health to the international scale.

Substantial changes in the basin have also led many to see Treaty review as an opportunity to update water management in the basin. The operating entities are studying options to explore before 2014 (U.S. Army Corps of Engineers and Bonneville Power Administration, Columbia River Treaty: 2012/2024 Review: Phase 1 Technical Studies 2009). A process of stakeholder input has begun on each side of the border. This review process provides an opportunity to consider governance of the basin in light of its adaptive capacity. Interviews with basin stakeholders suggest an interest in consideration of ecosystem function as a third purpose of the treaty, along with greater public involvement in both its negotiation and implementation (McKinney et al. 2010, University of Idaho and Oregon State University unpublished manuscript; http://water.oregonstate.edu/sites/ default/files/ui osu crt scenario development combined report final1.pdf). Viewing Treaty review as an opportunity to consider new approaches to river management requires understanding of the changes in the basin since 1964.

A symposium on the Columbia River Treaty held by the University of Idaho in collaboration with other basin universities in 2009 examined change and associated uncertainties both within and affecting the basin since 1964 in five categories: (1) change in values concerning the river; (2) change in the viability of populations of anadromous fish that spawn within the Columbia River system; (3) change in energy demand; (4) climate change; and (5) change in empowerment of local communities and, in particular, of Native American and First Nation governments. The following paragraphs will briefly summarize some of the important points raised at the symposium. A more complete 
summary is provided by Cosens (2010). It is important to note that not all of these changes are of equal importance to the two countries comprising the basin. Addressing change at the appropriate scale, rather than folding all issues into the international treaty, will be one of the important considerations in building capacity for adaptive governance.

Changes in societal values concerning the river are reflected in the adoption of new laws governing both the substance and process of natural resource management (Hirt and Sowards 2012). These new laws include the U.S. Endangered Species Act (ESA), adopted in 1973, which forbids federal actions that jeopardize listed species (16 U.S.C. $\S \S 1531-1544.2006$ ). Eight salmon and four steelhead species that rely on habitat within the basin have been listed in the United States, although numerous factors affect these species. Operation of the Federal Columbia River Power System (the part of the hydropower system at federal dams in the U.S. portion of the basin), has been the subject of numerous lawsuits under the ESA.

Dramatic changes in the health of the Columbia River ecosystem are reflected in the declines of populations of anadromous fish that spawn within the system and the blockage of anadromous fish from $37 \%$ of their former spawning grounds, including all of the river in Canada, by dams. Salmon have declined from an estimated high of 6-16 million in the early 1880s to < 1 million today (Peery 2012). The salmon fishery in the Columbia River basin is now supported by approximately 200 hatcheries (Peery 2012). It is difficult to argue that these changes were not foreseen (Bottom et al. 2009), but the value placed on the fisheries clearly has shifted.

In a 2009 special feature of Ecology and Society titled "Pathways to Resilient Salmon Ecosystems," scientists explored the prospects for Pacific salmon, including Columbia River populations. In contrast to the single population of Atlantic salmon, Pacific salmon have adapted to the relatively dynamic geological coastline and riverine environment of the west coast of North America through the development of multiple locally adapted populations (Waples et al. 2009). The 10-million-year survival of Pacific salmon in the face of a highly dynamic coastal environment is a tribute to their resilience (Healey 2009). However, anthropogenic changes have occurred on both a scale and timeframe that does not match historical geological variability in the system (Healey 2009). Thus, the key to restoring salmon resilience is not merely to maintain genetic diversity through hatcheries, but to re-establish the natural processes that led to adaptation (Healey 2009). Because salmon require the entire length of a river system, as well as the ocean, to complete their life cycle, this would require a daunting level of cross-jurisdictional coordination (Bottom et al. 2009).

Blockage of salmon from Canada by dams and new reliance on resident fisheries in the portions of the basin that no longer see salmon runs alters the dialogue surrounding ecosystem health in that portion of the river. Lake levels and release rates also affect these fisheries, just as they affect anadromous fish. Thus, even if the two nations comprising the basin have a different focus for ecosystem health domestically, coordination will be necessary for sustained health.

In addition, energy demand has not unfolded as was anticipated in 1964. When the 1964 Treaty was finalized, planners expected the rapid growth in power demand that followed World War II to continue. They expected new thermal generation to replace hydropower as the dominant source of energy in the Pacific Northwest (Shurts 2012). Conservation nation-wide in the wake of the 1970s energy crisis altered this picture, and hydropower remains the dominant energy source in the region (Hirt and Sowards 2012). Correspondingly, the system's value has grown dramatically. With the current push to develop non-carbon sources of energy, hydropower is likely to become even more valuable. The draft power plan released in September 2009 by the Northwest Power and Conservation Council indicates that "the most cost effective and least risky resource for the region" to meet electricity demand over the next 20 years "is improved efficiency of electricity use" (Northwest Power and Conservation Council 2010). Despite the 20-yr projections of the Council, energy demand and supply technology going forward may be just as unpredictable. Technology innovations in utility-scale storage, for example, could free up river operations for other purposes.

Under the 1964 Treaty, a high level of cooperation and joint planning for river operation occurs among the appointed operating entities. However, the type of agency-level (or entity-level) operational planning envisioned by the 1964 Treaty depends on seasonal and yearly variation that can be forecast within the degrees of historical variability. Six-year, one-year, and within-year planning cycles, as well as Supplemental Operating Agreements are used if mutual benefits in power, flood control, fisheries, or other values may be achieved (Barton and Ketchum 2012). In this way, the Treaty provides sufficient flexibility for adaptive management to account for seasonal and yearly uncertainty within the limited purposes of the Treaty.

Unfortunately, climate change predictions indicate that the range of variation will be greater than the variation predicted based on historical behavior (Hamlet 2003). Modeling by the Climate Impacts Group suggests that precipitation may not change dramatically within the Columbia River basin, albeit substantial uncertainty is associated with this statement (Hamlet 2003). However, changes in annual snowpack, which can be predicted with greater certainty, are already underway in the basin (Hamlet 2003, Nolin et al. 2012). The basin relies on snowpack as natural storage that, similar to reservoirs, moderates summer flows. With climate change, reduction in 
snow-water equivalent may be as much as $35 \%$ in the U.S. portion of the basin by 2060 and $12 \%$ in the Canadian portion of the basin (Hamlet 2003, Nolin et al. 2012). This reduction in natural storage means that the artificial storage configuration in the basin will be insufficient to reap the power benefits available in the past (Hamlet 2003). In particular, summer production, which serves utilities in the southwestern United States, will decrease if the current configuration is maintained (Hamlet 2003). Situations out of the historical water supply regime have impacts beyond power production. The Columbia River Treaty provides an excellent framework to address high flow. However, it does not address low flow under a climate change scenario (Hamlet 2003). Adaptation to climate change for other uses such as irrigation and fisheries requires responses by multiple agencies in the United States, with no framework for coordination (Hamlet 2003). Irrigation occurs during the summer, when the lowest flows will occur if storage is insufficient. If there is a failure to address low flows, the fish and farmers will bear the brunt of climate change (Hamlet 2003).

A more subtle yet pervasive change in laws governing process stems from the now global demand for greater public access to information and participation in governmental decision making. In the United States, the indications of this trend began with the passage of the Freedom of Information Act in 1966 (5 U.S.C. \$552. 2006) and the National Environmental Policy Act in 1970 (Pub. L. No. 91-190, 83 Stat. 852. 1970; current version at 42 U.S.C. $\S$ 4321. 2006; Hirt and Sowards 2012).

A reconnaissance-level situation assessment of stakeholders in the Columbia River basin was done by students at the University of Montana under the direction of consortium member Dr. Matthew McKinney (McKinney et al. 2010). This assessment, along with subsequent interviews done by students at the University of Idaho and Oregon State University (unpublished manuscript) confirmed the expectation of public input within the basin and identified several key perceptions. Among the key issues identified by stakeholders that were not addressed in 1964 but should be in the future is participation by affected communities, including Native American tribes and First Nations. This perception is paralleled by the dramatic change in empowerment among basin communities.

The following factors, detailed in Cosens (2010), have increased empowerment of local communities and, in particular, of Native American and First Nation governments resulting in enhanced capacity to participate in Columbia River decision making: (1) legal recognition of the treaty rights of certain Native American tribes to participate in the harvest and management of Columbia basin fisheries within the United States, now organized as the Columbia River Intertribal Fish Commission; (2) recognition of the upper basin tribes within the United States whose land was blocked from anadromous fish migration by the Grand Coulee Dam, organized as the Upper Columbia United Tribes; (3) establishment of the Northwest Power and Conservation Council in the United States in 1980, composed of state representatives in the United States portion of the basin and charged with energy and fisheries restoration planning; (4) Constitutional recognition of the rights of First Nations in Canada in 1982; and (5) legislative recognition of the Columbia Basin Trust in Canada in 1995, formed initially as a grassroots effort to assert the rights of local communities and First Nations whose lands were flooded by Treaty dams. Many of these groups advocate restoration of the health of anadromous fish runs in the basin, although some have shifted focus to resident fish and cultural restitution in areas blocked from salmon runs. These changes parallel the growing call for public participation in resource management decisions and the need for local capacity building to make this input a reality. They provide the base from which public processes can be built into adaptive governance.

Adaptive management was attempted in the late 1980s to early 1990s in the U.S. portion of the Columbia River basin as part of a fish and wildlife restoration effort, and failed. That failure must be assessed if consideration of a new attempt is to be credible. The following section relies on the extensive analyses of that failure to place it in the context of the differences between adaptive management and adaptive governance and the framework for legitimacy.

\section{MOVING FROM ADAPTIVE MANAGEMENT TO ADAPTIVE GOVERNANCE}

The Northwest Power Act of 1980 (Pacific Northwest Electric Power Planning and Conservation Act, Pub. L. No. 96-501, 94 Stat. 2697) brought great hope to those interested in restoring anadromous fish runs in the U.S. portion of the Columbia River basin. The Act is an interstate compact approved by the legislatures of Idaho, Montana, Oregon, and Washington, and by Congress to give the four states a greater role in decision making with respect to electric power and fish and wildlife in the U.S. portion of the Columbia River basin. The resulting Northwest Power and Conservation Council (hereafter, the Council) comprises two political appointees from each state, has legal and technical staff, and is funded through power revenues from the Bonneville Power Administration. The Council has three primary objectives: (1) develop a 20-yr electric power plan that will guarantee adequate and reliable energy at the lowest economic and environmental cost to the Northwest; (2) develop a program to protect and rebuild fish and wildlife populations affected by hydropower development in the Columbia River basin; and (3) educate and involve the public in the Council's decisionmaking processes.

The Act requires all actions of the Bonneville Power Administration to be consistent with the Council's electric 
power plan. In contrast, the fish and wildlife program is intended to be based on input from states, tribes, and federal agencies, and to complement their activities, but no authority is granted to the Council or the Bonneville Power Administration to reconcile the fish and wildlife program with hydropower operations in the basin (Volkman and McConnaha 1993). Hope that the Council's activities would reverse the decline of anadromous fish was sufficiently high that a process for listing of spring chinook salmon under the ESA was set aside pending implementation of the new program (McConnaha and Paquet 1996).

Washington appointee to the Council, Dr. Kai Lee, introduced the concept of adaptive management in the initial years of implementation of the Act (Volkman and McConnaha 1993, see also Lee 1993, 1999). Adaptive management was embraced for application of the fish and wildlife program restoration activities initially, then extended to mainstem flow operations by amendments to the program in 1994 (Independent Scientific Group 1996, Blumm 2002). This extension was never implemented. Its implementation was rejected when the political make-up of Council members changed (McConnaha and Paquet 1996, Blumm 2002). Reconsideration was preempted by listing under the ESA (discussed as an attractive alternative below). The effort to apply adaptive management to fish and wildlife restoration activities failed. If adaptive management is to be recommended as one tool for moving the Columbia River basin toward a more resilient social-ecological system, it is first necessary to analyze why the original experiment in adaptive management failed, and second, by viewing it through the framework of legitimacy, to consider whether there is any reason to believe it would succeed if tried again.

Published analyses of attempted adaptive management on the U.S. portion of the Columbia River basin suggest a variety of reasons for failure that generally fit into four categories: implementation, geographic scale, time scale, and attractive alternative. Each of these categories is discussed below in the context of legitimacy, followed by a discussion of the Council's efforts in public participation, which are closer to the model sought for legitimacy in adaptive governance.

\section{Implementation}

Analyses by both program participants and an independent group of scientists indicate that the crucial steps in adaptive management of monitoring, evaluation, and adjustment were not rigorously adhered to in the Council's effort. Monitoring focused on salmon rather than the key ecological features needed to support them (Independent Scientific Group 1986), leading to a bias in favor of hatchery programs rather than attention to the full range of ecosystem function. The cost of monitoring tended to result in its elimination from project funding (Lee and Lawrence 1986). To assure results-based legitimacy, goal setting followed by monitoring of actions must be presented to legislative appropriation committees as vital program components needed to assure agency accountability. Giving a program the tools to demonstrate that its actions are either moving the ecological system in the direction of its ecological goals or that adjustments must be made if they are not is the key to returning legitimacy to resultsbased decision making.

Where monitoring was used in the Council's program, evaluation of results occurred at the program level by policy and decision makers, not by independent scientists (Independent Scientific Group 1996). This eliminated the opportunity to make scientific adjustments to monitoring to reduce uncertainty (McConnaha and Paquet 1996). Huitema et al. (2009) note that Lee's (1999) description of involving decision makers is closer to the model for adaptive governance. However, it may also reflect a failure to distinguish between governance and implementation of management. To maintain the integrity of results-based legitimacy, scientific monitoring results must be interpreted by scientists. Likewise, the recommendation for adjustments must also come from the scientific community. Science-based recommendations may be rejected in the process of making trade-offs, but by doing so in open deliberative processes rather than hiding the rejection in the uncertainty surrounding the science, the possibility of resorting to the status quo is reduced and the transparency necessary for legitimacy is enhanced.

Implementation problems can also be addressed through attention to deliberative legitimacy. Goal setting must be done through a deliberative process by bringing together scientific expertise to identify measurable goals and public input at the scale of the impact of the particular action. Monitoring must be funded and employed to measure variables that are relevant to the goal set. The analysis and adjustment stage then becomes the avenue to results-based legitimacy.

The decision to extend adaptive management to mitigation of mainstem power operations on fish was never implemented. A barrier to its success, had it been implemented, was the fact that the fish and wildlife program could only guide, not control, decisions on power operations (Volkman and McConnaha 1993). As noted, under the 1964 Treaty, changes to power operations to accommodate fish migration have taken place. However, the benefit to Canada of U.S. power production is calculated without recognizing those accommodations. The fact that the United States loses power generation for fish flows, then provides power benefits to Canada as if that loss did not occur, creates a disincentive to alter operations for fish. The elevation of ecosystem function to an international consideration provides a forum for decision making in which both the action (power generation) and its impact on the ecosystem are deliberated at the same scale and level of governance. 


\section{Geographic scale}

Analyses indicate that the lack of overarching authority in a jurisdictionally complex basin, the difficulty of experimental design, and concern over experimentation with species, thought by some to be on the brink of extinction, all plagued the Council's fish and wildlife program. Potentially, the greatest barrier to success lay in the competing and conflicting goals between the Council's stated objective to develop a fish and wildlife program and international operation of the river for the primary purposes of hydropower and flood control. Had implementation and time scale issues been cured, it is likely that the Council's adaptive management program would have worked well on the sub-basin scale. The problems in moving to an adaptive approach applied to actions that have implications at a basin-wide scale, such as mainstem dam operation, are twofold.

First, the complexity of experimental design and meaningful monitoring at this scale cannot be fully eliminated. Experimentation on the scale of an entire river basin is both jurisdictionally (Lee and Lawrence 1986, McConnaha and Paquet 1996) and scientifically complex (McConnaha and Paquet 1996) and possibly unwise given that the risk of failure extends to the entire basin. These problems are compounded when the species in question is in decline. Because large-scale experimentation on species in decline has high risks, it is extremely difficult to generate the political will to act (Volkman and McConnaha 1993). Nevertheless, it is important to recognize that dam construction and daily dam operations are themselves major experiments in ecological resilience. Viewed through this lens, if the problem of exactly what to monitor to separate out impacts due to changes in dam operation from those due to changes in ocean conditions, harvest, and other variables is solved, incremental changes are simply adjustments to an experiment that is already underway.

The second problem with geographic scale is the need for coordination across multiple jurisdictions to address problems at a basin scale. Although matching the scale of governance to the scale of the problem is frequently discussed (Ruhl and Salzman 2010), scholars caution that complex systems often require action at a variety of scales (Ruhl and Salzman 2010). The observed need for flexibility to adapt to the scale of a particular problem supports the call for polycentricity as a component of adaptive governance. This and the pragmatic recognition that legitimate democratic systems cannot merely replace an existing multi-jurisdictional system with a single basin-wide authority lead to the conclusion that coordination at the scale of the basin should be addressed through a network approach rather than elevating all decisions to a basin-wide authority. Changes are nevertheless needed to implement any network approach and must include coincidence of goals, time scale, monitoring, and process on the issue in question across network organizations. It is likely that this requires, at the very least, authority incorporated at the highest jurisdictional level to authorize treatment of ecosystem health at a level equivalent to hydropower and flood control. In the case of the Columbia River basin, this would be at the level of the international treaty.

\section{Time scale}

Adaptive management requires monitoring the response to a particular action for a sufficient period of time. This will provide biologically meaningful data so that informed decisions can be made on adjustments to management. The political time scale is generally much shorter than the biological one (Lee and Lawrence 1986, Volkman and McConnaha 1993). In the Columbia basin, the political shift that took place between program amendments to adopt adaptive management for mainstem fish passage and implementation of adaptive management on the mainstem derailed the effort (Blumm 2002). In addition, the patience of salmon advocates ran out and an attractive alternative was available (i.e., listing under the ESA). For order-based legitimacy, the time scale of incremental adjustment to management decisions must reflect both biological and social needs. Reconciling the ecological and social time scales in making incremental changes to management must be achieved through deliberative processes. Rate of change in components of an ecological system should be factored into considerations of what to monitor. At the same time, it must be acknowledged that economic stability does not require absolute finality. Incremental adjustments made on a time scale that takes the investment cycle into account will not destabilize the system. By elevating the dialog to the basin level, thus bringing fish restoration and power generation into the same decisionmaking process, a timeframe that meets both needs is more likely to be found. Currently, instability under the ESA tracks the federal election cycle. The gridlock and litigation expense created by that process should cause some to consider a 10 20 -yr cycle of change to be a reasonable approach.

\section{Attractive alternative}

Frustrated with the slow pace of action under the Northwest Power Act and the interpretation of the Bonneville Power Administration that it need not comply precisely with the recommendations of the Council, salmon advocates turned to an attractive, more robust alternative, the Endangered Species Act. The absolute prohibition on jeopardy in the ESA appeared to be the necessary hammer to change mainstem federal dam operation. Twelve populations of Columbia River salmon and steelhead and two resident Columbia River species of fish have been listed since the early 1990s.

An analysis of the compatibility of the ESA and adaptive management written by Council staff after the initial Snake River listings was cautiously optimistic (Volkman and McConnaha 1993). The authors noted that the focus of adaptive management would probably change from hatcheries to wild fish due to the listing, and that risky experimentation 
would be prevented by the ESA prohibition on jeopardy of listed species by federal action. The authors also noted that experimentation would nevertheless be feasible provided the implementation of adaptive management did not lead to a stalemate "over suitable hypotheses and experimental measures" (Volkman and McConnaha 1993:1272). Unfortunately, litigation and focus on disputes over uncertain science prevailed over the optimistic scenario thought possible.

Many believe that the current ESA implementation in the Columbia River basin is in a stalemate. The stalemate concerns the science behind a determination of jeopardy or no jeopardy rather than the science behind an evolving process of adaptive management for purposes of restoration (Thomas-Morse 2012). The process of consultation under the ESA by the U. S. National Marine Fisheries Service (NOAA Fisheries) took on the appearance of politicized science when the Biological Opinion on operation of the Federal Columbia River Power System flipped from one of jeopardy under the Clinton administration to one of no jeopardy under the Bush administration (Thomas-Morse 2012). Whether a valid accusation or not, its reception clearly signaled a loss of legitimacy for ESA implementation in the Columbia River basin. In addition, it has become clear that "no jeopardy" falls short of management for ecosystem resilience (G. Hill and S. Kolmes, personal communication). Finally, ESA implementation has run into the same barrier that implementation by the Council faced. Because it applies only on the U.S. side of the border, agencies have attempted to keep implementation within the parameters of the 1964 Treaty. Under U.S. domestic law, a later-enacted domestic statute (e.g., the 1973 ESA) prevails over a treaty, despite the fact that under international law, this will place the United States in breach of the 1964 Treaty (Rogers 1999). Thus, U.S. entities seek to implement domestic law in a manner that avoids conflict with a treaty, limiting the range of possible measures.

Thus, the attractive alternative of ESA listing relied on in the 1990s has not lived up to its promise. At the same time, the threat of ESA sanctions has been a factor in balancing the dialog in the basin and can remain an equalizing force. It is the means to achieve its goals that require a new approach. Lack of success under the ESA should encourage its proponents to consider a new methodology. With no permanent solution in sight after almost twenty years of litigation, parties may be more receptive to an adaptive approach that holds future actions accountable to measured progress.

\section{Public participation}

The Council underwent an extensive sub-basin planning process to inform its identification of priorities under the fish and wildlife program (Volkman and McConnaha 1993). The intent, under the leadership of Dr. Lee, was to integrate economic and social concerns in restoration efforts (Volkman and McConnaha 1993). This approach is an important aspect of legitimacy, and the Council has been praised for these efforts (Volkman and McConnaha 1993). At the same time, the Council itself is composed of representatives of the four basin states (leaving off the minor portions of Wyoming and Nevada in the basin); however, there are also 15 Native American reservations within the U.S. portion of the basin. Under the sub-basin planning process, participation by tribes would be as members of the public rather than as sovereigns. Any new effort to implement adaptive management in the basin can turn to the sub-basin planning process as a model of public participation. However, achieving adaptive governance must also include a recognized role for the 15 tribal sovereigns, separate from the general public. By viewing governance in the basin as polycentric, appropriate roles for tribal, state, and international governance can be addressed separate from the development of a robust process for public input.

\section{CONCLUSION}

The current review of the Columbia River Treaty provides an opportunity to consider river governance at the scale of international river management. If stakeholders seek a more resilient form of river governance, it will require a change in the operations and implementation of the Treaty to allow more flexible response at the international level and greater local input and coordination on efforts to restore ecosystem health. The entities necessary to provide multiple, overlapping authority now exist in the Columbia River basin, but it is their input to the Treaty and operational decisions and their role in implementation that require acceptance at the international level. The groundwork for connecting local knowledge and input to national-level decisions has been laid in the Columbia River basin by substantial increases in local capacity since ratification of the 1964 Treaty.

Too often, scientific studies of ecological systems view the legal and political system as boundary conditions. By focusing research on those boundaries and how to move them, greater implementation of emerging approaches to management for resilience may be achieved. This will require changes to both governance and the implementation of policy through management. The current gap between the recognition by resilience scientists that adaptive management is an appropriate management tool in the face of uncertainty and achieving its implementation may be bridged by recognition of the difference between scientific accuracy and social legitimacy and full integration of the social component. Implementation of the flexibility required for adaptive management must be accompanied by careful attention to the use of scientific expertise and its separation from the tradeoffs made by decision makers, consideration of both the biological and social components in the choice of timeframes for adjustment of management actions, and a robust, deliberative public process supported by local capacity building to allow 
meaningful participation. Analysis of the changes necessary to ensure legitimacy in governance provide another lens to analyze the value of polycentricity, public participation, an experimental approach to resource management, and management at the bioregional scale as components of good water governance.

Responses to this article can be read online at: http://www.ecologyandsociety.org/issues/responses. php/4986

\section{LITERATURE CITED}

Barton, J., and K. Ketchum. 2012. Columbia River Treaty: managing for uncertainty. In $\mathrm{B}$. Cosens, editor. The Columbia River Treaty revisited: transboundary river governance in the face of uncertainty. Oregon State University Press, Corvallis, Oregon, USA.

Blumm, M. C. 2002. Sacrificing the salmon: a legal and policy history of the decline of Columbia basin salmon. BookWorld Publications, Den Bosch, The Netherlands.

Bodansky, D. 1999. The legitimacy of international governance: a coming challenge for international environmental law? American Journal of International Law 93:596-624. http://dx.doi.org/10.2307/2555262

Bodin, O., and B. I. Crona. 2009. The role of social networks in natural resource governance: What relational patterns make a difference? Global Environmental Change 19(3):366-374. http://dx.doi.org/10.1016/j.gloenvcha.2009.05.002

Bottom, D., K. Jones, C. Simenstad, and C. Smith, editors. 2009. Pathways to resilient salmon ecosystems. Ecology and Society 14(1): 34 [online] URL: http://www.ecologyandsociety. org/issues/view.php?sf=34.

Boyle, M., J. Kay, and B. Pond. 2001. Monitoring in support of policy: an adaptive ecosystem approach. Pages 116-137 in T. Munn, editor. Encyclopedia of global environmental change, volume 4. Wiley, London, UK.

Camacho, A. E. 2009. Adapting governance to climate change: managing uncertainty through a learning infrastructure. Emory Law Journal 59(1):1-77.

Cosens, B. 2008. Resolving conflict in non-ideal, complex systems: solutions for the law-science breakdown in environmental and natural resource law. Natural Resources Journal 48:257-301.

Cosens, B. 2010. Transboundary river governance in the face of uncertainty: resilience theory and the Columbia River Treaty. Journal of Land, Resources and Environmental Law 30(2):229-265.
Cosens, B. 2012. Legitimacy, adaptation, and resilience in ecosystem management. Ecology and Society, in press. http:// dx.doi.org/10.2139/ssrn.1942875

Doremus, H., and A. D. Tarlock. 2005. Science, judgment, and controversy in natural resource regulation. Public Land and Resources Law Review 26:1-37.

Esty, D. C. 2006. Good governance at the supranational scale: globalizing administrative law. Yale Law Journal 115:1490-1562. http://dx.doi.org/10.2307/20455663

Folke, C., T. Hahn, P. Olsson, and J. Norberg. 2005. Adaptive governance of social-ecological systems. Annual Review of Environment and Resources 30:441-473. http://dx.doi. org/10.1146/annurev.energy.30.050504.144511

Hamlet, A. F. 2003. The role of transboundary agreements in the Columbia River basin: an integrated assessment in the context of historic development, climate, and evolving water policy. Pages 263-289 in H. F. Diaz and B. J. Morehouse, editors. Climate and water: transboundary challenges in the Americas. Kluwer, Dordrecht, The Netherlands.

Hanna, S. S. 2008. Institutions for managing resilient salmon (Oncorhynchus spp.) ecosystems: the role of incentives and transaction costs. Ecology and Society 13(2): 35. [online] URL: http://www.ecologyandsociety.org/vol13/iss2/art35/.

Healey, M. C. 2009. Resilient salmon, resilient fisheries for British Columbia, Canada. Ecology and Society 14(1): 2. [online] URL: http://www.ecologyandsociety.org/vol14/iss1/ art2/.

Hirt, P. W. 2008. Developing a plentiful resource: transboundary rivers in the Pacific Northwest. Pages 147-188 in J. M. Whiteley, H. Ingram, and R. Perry, editors. Water, place, and equity. MIT Press, Cambridge, Massachusetts, USA.

Hirt, P. W., and A. M. Sowards. 2012. The past and future of the Columbia River. In B. Cosens, editor. The Columbia River Treaty revisited: transboundary river governance in the face of uncertainty. Oregon State University Press, Corvallis, Oregon, USA.

Holling, C. S., editor. 1978. Adaptive environmental assessment and management. Wiley, London, UK.

Holling, C. S., and L. H. Gunderson. 2002. Resilience and adaptive cycles. Pages 25-62 in L. H. Gunderson and C. S. Holling, editors. Panarchy: understanding transformations in human and natural systems. Island Press, Washington, D.C., USA.

Huitema, D., E. Mostert, W. Egas, S. Moellenkamp, C. PahlWostl, and R. Yalcin. 2009. Adaptive water governance: assessing the institutional prescriptions of adaptive (co-) management from a governance perspective and defining a 
research agenda. Ecology and Society 14(1): 26. [online] URL: http://www.ecologyandsociety.org/vol14/iss1/art26/.

Independent Scientific Group. 1996. Return to the river: restoration of salmonid fishes in the Columbia River ecosystem: development of an alternative conceptual foundation and review and synthesis of science underlying the fish and wildlife program of the Northwest Power Planning Council. Northwest Power and Conservation Council, Portland, Oregon, USA. [online] URL: http://www. nwcouncil.org/library/1996/96-6/default.htm.

Kosso, P. 2007. Scientific understanding. Foundations of Science 12(2):173-188. http://dx.doi.org/10.1007/s10699-006-0002-3

Landeen, D., and A. Pinkham. 2008. Salmon and his people: fish and fishing in Nez. Perce culture. Confluence Press, Lewiston, Idaho, USA.

Langston, N. 2003. Where land and water meet: a Western landscape transformed. University of Washington Press, Seattle, Washington, USA.

Lee, K. N. 1993. Compass and gyroscope: integrating science and politics for the environment. Island Press, Washington, D. C., USA.

Lee, K. N. 1999. Appraising adaptive management. Conservation Ecology 3(2): 3. [online] URL: http://www. consecol.org/vol3/iss2/art3/.

Lee, K. N., and J. Lawrence. 1986. Adaptive management: learning from the Columbia River basin fish and wildlife program. Environmental Law 16:431-460.

McConnaha, W. E., and P. J. Paquet. 1996. Adaptive strategies for the management of ecosystems: the Columbia River experience. American Fisheries Society Symposium $16: 410-421$.

McKinney, M., L. Baker, A. M. Buvel, A. Fischer, D. Foster, and C. Paulu. 2010. Managing transboundary natural resources: an assessment of the need to revise and update the Columbia River Treaty. West-Northwest Journal of Environmental Law and Policy 16(2):307-350.

McKinney, M., and W. Harmon. 2004. The Western confluence: a guide to governing natural resources. Island Press, Washington, D.C., USA.

Mouat, M. 2012. The Columbia exchange: a Canadian perspective on the negotiation of the Columbia River Treaty. In B. Cosens, editor. The Columbia River Treaty revisited: transboundary river governance in the face of uncertainty. Oregon State University Press, Corvallis, Oregon, USA.

Nolin, A., E. Sproles, and A. Brown. 2012. Climate change impacts on snow and water resources in the Columbia, Willamette, and McKenzie River basins, USA: a nested watershed study. In B. Cosens, editor. The Columbia River
Treaty revisited: transboundary river governance in the face of uncertainty. Oregon State University Press, Corvallis, Oregon, USA.

Northwest Power and Conservation Council. 2010. Sixth Northwest conservation and electric power plan. Northwest Power and Conservation Council, Portland, Oregon, USA. [online] URL: http://www.nwcouncil.org/energy/powerplan/6/ default.htm.

O'Reilly, K. 2007. Science, policy, and politics: the impact of the Information Quality Act on risk-based regulatory activity at the EPA. Buffalo Environmental Law Journal 14:249-287.

Peery, C. 2012. The effects of dams and flow management on Columbia River ecosystem processes. In B. Cosens, editor. The Columbia River Treaty revisited: transboundary river governance in the face of uncertainty. Oregon State University Press, Corvallis, Oregon, USA.

Raadgever, G. T., E. Mostert, N. Kranz, E. Interwies, and J. G. Timmerman. 2008. Assessing management regimes in transboundary river basins: Do they support adaptive management? Ecology and Society 13(1): 14. [online] URL: http://www.ecologyandsociety.org/vol13/iss1/art14/.

Rogers, J. M. 1999. International law and United States law. Dartmouth Publishing, Aldershot, UK.

Roth, D., R. Boelens, and M. Zwarteveen, editors. 2005. Liquid relations: contested water rights and legal complexity. Rutgers University Press, New Brunswick, New Jersey, USA.

Ruhl, J. B., and J. Salzman. 2010. Climate change, dead zones, and massive problems in the administrative state: a guide for whittling away. California Law Review 98:59-120.

Shabman, L., D. Reckhow, M. B. Beck, J. Benaman, S. Chapra, P. Freedman, M. Nellor, J. Rudek, D. Schwer, T. Stiles, and C. Stow. 2007. Adaptive implementation of water quality improvement plans: opportunities and challenges. Nicholas Institute, Duke University, Durham, North Carolina, USA.

Shurts, J. 2012. Rethinking the Columbia River Treaty. In B. Cosens, editor. The Columbia River Treaty revisited: transboundary river governance in the face of uncertainty. Oregon State University Press, Corvallis, Oregon, USA.

Thomas-Morse, C. 2012. When courts run regulated rivers: the effects of scientific uncertainty. In B. Cosens, editor. The Columbia River Treaty revisited: transboundary river governance in the face of uncertainty. Oregon State University Press, Corvallis, Oregon, USA.

U.S. Army Corps of Engineers and Bonneville Power Administration. 2009. Columbia River Treaty: 2012/2024 Review: Phase 1 Technical Studies. U.S. Army Corps of Engineers and Bonneville Power Administration, Washington, 
D.C., and Portland, Oregon, USA. [online] URL: http://www. bpa.gov/corporate/pubs/Columbia River Treaty Review 2 April 2009.pdf.

Volkman, J. M., and W. E. McConnaha. 1993. Through a glass, darkly: Columbia River salmon, the Endangered Species Act, and adaptive management. Environmental Law 23:1249-1272.

Wagner, W. E. 1995. The science charade in toxic risk regulation. Columbia Law Review 95:1613-1723. http://dx. doi.org/10.2307/1123193

Walker, B., and D. Salt. 2006. Resilience thinking: sustaining ecosystems and people in a changing world. Island Press, Washington, D.C., USA.

Waples, R. S., T. Beechie, and G. R. Press. 2009. Evolutionary history, habitat disturbance regimes, and anthropogenic changes: What do these mean for resilience of Pacific salmon populations? Ecology and Society 14(1): 3. [online] URL: http://www.ecologyandsociety.org/vol14/iss1/art3/.

White, A. 2012. The Columbia River, its treaties and operation. In B. Cosens, editor. The Columbia River Treaty revisited: transboundary river governance in the face of uncertainty. Oregon State University Press, Corvallis, Oregon, USA.

White, R. 1995. The organic machine: the remaking of the Columbia River. Hill and Wang, New York, New York, USA.

Zaring, D. 2009. Three challenges for regulatory networks. International Lawyer 43(1):211-217.

Zellmer, S., and L. Gunderson. 2009. Why resilience may not always be a good thing: lessons in ecosystem restoration from Glen Canyon and the Everglades. Nebraska Law Review 87 (4):893-949. 